\title{
Research on Color Application of Art-Deco Style
}

\author{
Chao Huang \\ Nankai University Binhai College \\ Tianjin Binhai New Area \\ Tianjin, China
}

\author{
Liyuan $\mathrm{Hu}$ \\ Nankai University Binhai College \\ Tianjin Binhai New Area \\ Tianjin, China
}

\begin{abstract}
The Art-Deco style is a popular style in the 1930s and 1940s. This style originated in Paris, France. It focuses on expressing the luxury and novelty characteristics of Paris France and it was deeply favored by the people at that time. The color of Art-Deco style has many unique artistic features, it is colorful, bright, and has a very artistic atmosphere. If we can apply this color feature to modern design, we can better pass on it and also we can better develop the characteristics of the Art-Deco style in the context of such a diversified design style, so that we can design more suitable environments for people's lives and survival. This article is based on the overview of Art-Deco style and its color characteristics, and through the discussion of actual application situation of Art-Deco style in different design fields, finally analyzes the specific application of Art-Deco style in Dolce \& Gabbana brand.
\end{abstract}

Keywords-art-deco style; color; application; Dolce \& Gabbana

\section{INTRODUCTION}

The 20-30s of the 20th century was a unique period in history. First people in this period were in the middle of two world wars. All parts of Europe were in the war. The cruelty of war made many people suffer. Many people hope to be able to quickly pass through this cruel period; On the other hand, the new century has brought a lot of fresh things to people, European art and design circles have also begun to try reforms, and the traditional art design style has gradually changed. The traditional view of color has also gradually changed. Under such background, the Art-Deco style has emerged.

\section{CONCEPTS RELATED TO COLOR APPLICATION RESEARCH IN ART-DECO STYLE}

\section{A. Overview of Art-Deco Style}

The Art Decoration style, also known as the "Art-Deco" style, was born in the early 1920 s and later translated into the
Art-Deco School, Art-Deco style, modern style and so on. It was popular in Europe and America in the 1920s and 1930s, and it was officially named after the 1925 Paris International Decorative Arts and Modern Industry Fair.

The Art-Deco style combines the mechanical aesthetics which rose in the era of industrial culture. It inherits the simple, mechanical and geometric artistic features of mechanical aesthetics very well. From the modeling, it prefers to use fanshaped radiation shapes, gear or streamlined lines, symmetrical simple geometric composition, etc.; from the color, it prefers to use relatively bright colors to draw. At the same time it emphasizes the combination of modernity, innovation and machine production, while retaining many traditional factors. From the bright, lively and elegant stage of the birth in Paris to the streamlined branches of the United States' "Art-Deco" in the later period, "Art-Deco" is regarded as "the most exciting decorative art style in the 20th century".

\section{B. Basic Principle and Research Method of NCD Color Application System}

1) Basic principle of NCD color application system: The NCD color system designed by the Color Research Institute of Japan is based on Mensell's color principle in "Fig. 1" and further systematized and systematized it, built a new system full of man-made environment on the basis of sociology, graphics, and psychology. This new system could further reorganize and reconstruct cultural genes, thereby establishing a more meaningful color image system. Its formation theory system and research methods have been widely approved and accepted by the world's color science community. 

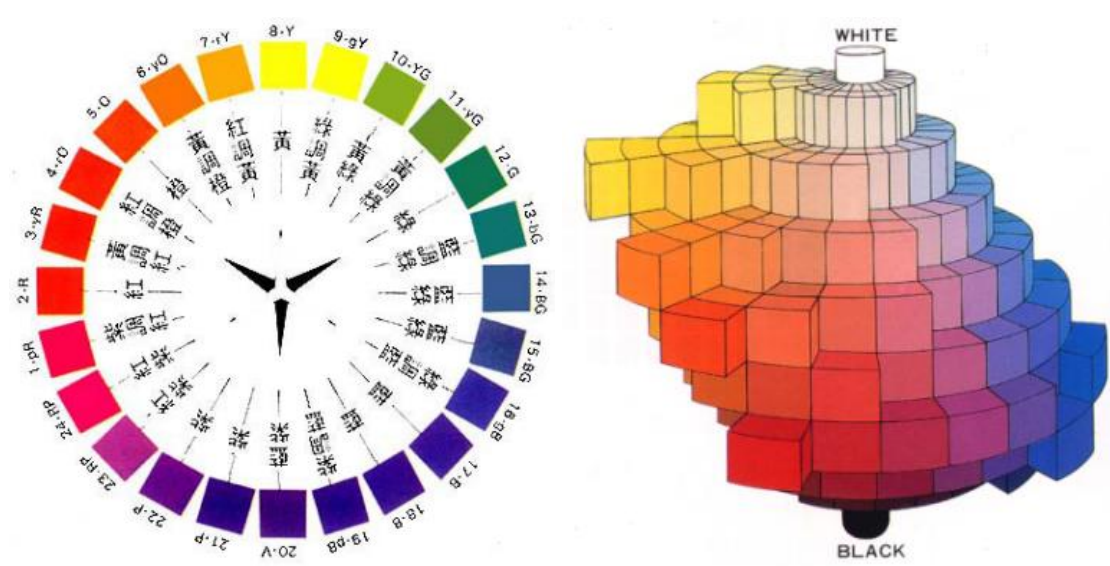

Fig. 1. Mensell's hue circle and color stereo. Source: Baidu Images

The specific basic principles include the following sections:

1. Representative color: more than 130 kinds of monochrome represent infinite color image world, and each kind of monochrome is explained by one page of data materials.

2. In the main color matching image mode, use the representative color matching, and the basic color matching image is expanded and can be clearly represented on the image coordinates through the distribution area.

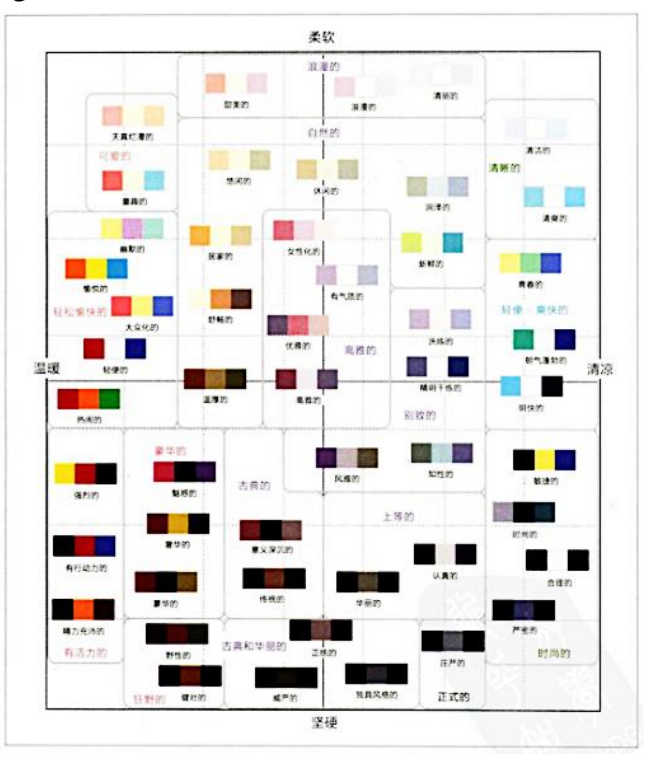

3. Through the color matching expressing mode, the representative color frequency index is divided into 5 levels, which are represented by star.

The basic working model of the NCD is the color image coordinates and the language image coordinates in "Fig. 2". One or more colors in the color image coordinates are summarized by each adjective on the coordinate axis, so that the designer can make the color matching with more scientific basis, and also allow them to use colors more skillfully.

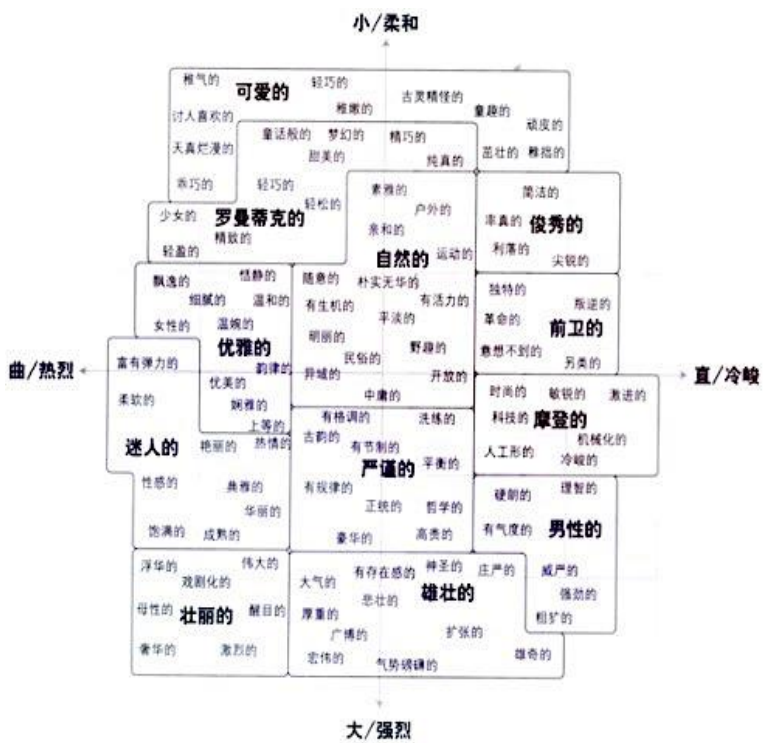

Fig. 2. Color image coordinates and adjective coordinates. Source: color psychoanalysis.

2) Research method: The literature survey method was used to investigate the basic situation of the project, so as to lay a good foundation for the better writing of the thesis in the later period. The case law is used to analyze and elaborate the classic design cases of Art-Deco style, so as to deeply analyze the color matching style and the style of Art-Deco. Using the comprehensive application method to conduct in-depth discussions on the topic, combining the Dolce \& Gabbana brand's overall design style with the Art-Deco color matching approach to explore a design that is more suitable for the brand's specialty stores, so that to make better display and improve the artistic effects and brand appeal of this brand.

\section{COLOR CHARACTERISTICS AND PSYCHOLOGICAL IMPACT OF ART-DECO STYLE}

\section{A. Color Matching Principles of Art-Deco Style}

1) Hue matching: Hue matching is the first principle of color matching of Art-Deco style. Hue matching use 4-5 hues 
for color matching, when the hue type reaches 4 kinds, it can be added with black, and when the hue type reaches 5 kinds, then cold color can not be more than 2 kinds. The lustrous effect between colors could be more attractive to people's eyes, which can give a screen effect of rich artistic features for the picture. When use this model for color matching, after determining a main color, it can be better combined with other colors to make it a clear contrast.

TABLE I. COLOR ANALYSIS

\begin{tabular}{|c|c|c|}
\hline Illustration & \multicolumn{1}{|c|}{ Color Description } \\
\hline The main color in the work is red, which \\
can evoke emotions such as fullness, \\
ambition, determination, joy, and victory. \\
At the same time, the yellow of the \\
collocation colors increases the vitality of \\
the work, and the blue is more youthful. \\
The entire work can bring a "warm and \\
happy feeling" to people's eyes.
\end{tabular}

"Table I" is an Art-Deco style design work using hue matching. From this design work, the middle figure in the work is dominated by red color to highlight the focus, and the rest positions are mainly composed of two colors: yellow and blue. The contrast between the three primary colors makes the whole work a very luxurious feeling and brings people with extremely rich artistic features. The jewellery in "Table II" is also a jewellery work mainly composed of hue matching. The whole work is composed of three kinds of gems: emeralds, rubies and sapphire. The three types of gems are contrasted by silver-white diamonds, making the connection of the entire jewelry more natural and harmonious and become the center of attention.

TABLE II. COLOR ANALYSIS

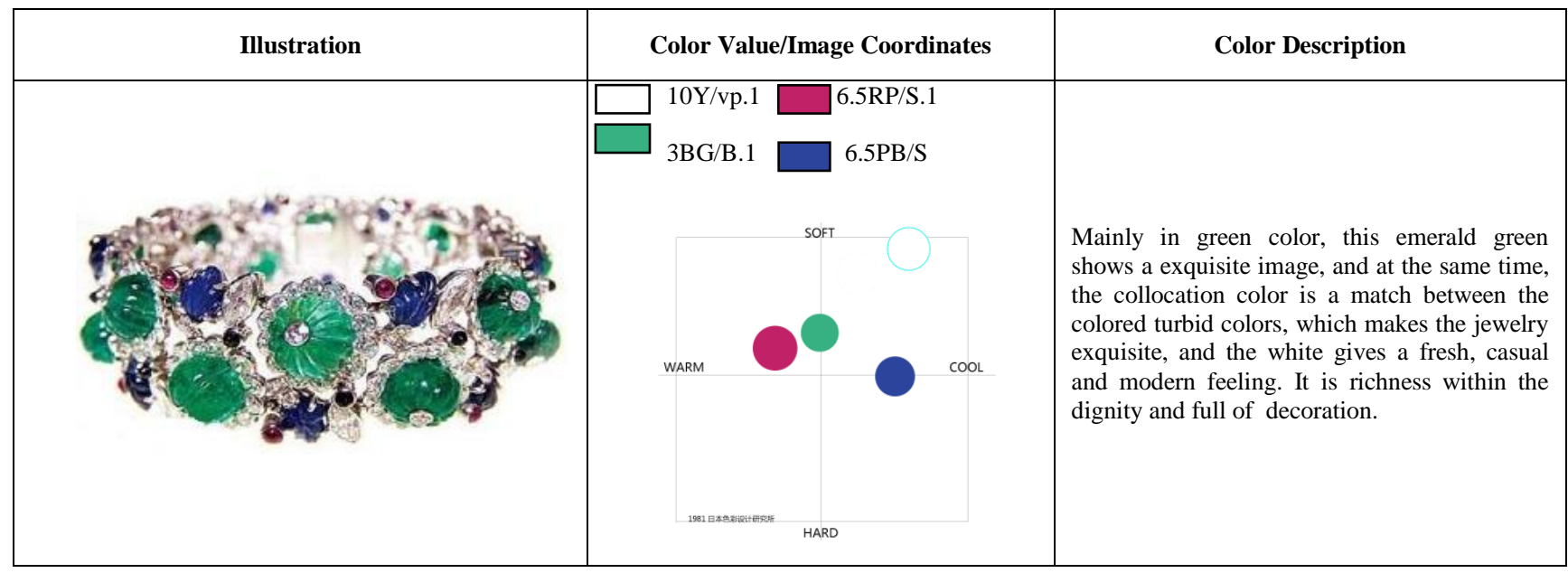

2) Color separation: Color separation, that is, in order to express the contrast of the hues, and make radial arrangement for cold and warm colors. In order to express the brightness difference of the color, and make radial arrangement for the contrast tones and the contrast hues, and black and white color could be added to make the effect of the color separation more obvious.

"Table III" is a typical Art-Deco graphic design work. In this work, the red color in the middle is particularly high purity, and the color is very conspicuous. People see this design work and will immediately focus on this piece of color. On the contrary, the colors in other locations are dominated by blue, yellow and black. However, the purity of these colors is relatively low, and the black makes the effect of color separation more obvious. This pure gray matching art screen not only highlights the textual content that need to be the key points display, and also balance the effect of the entire screen cleverly to achieve a very good artistic effect and visual impact. 
TABLE III. COLOR ANALYSIS

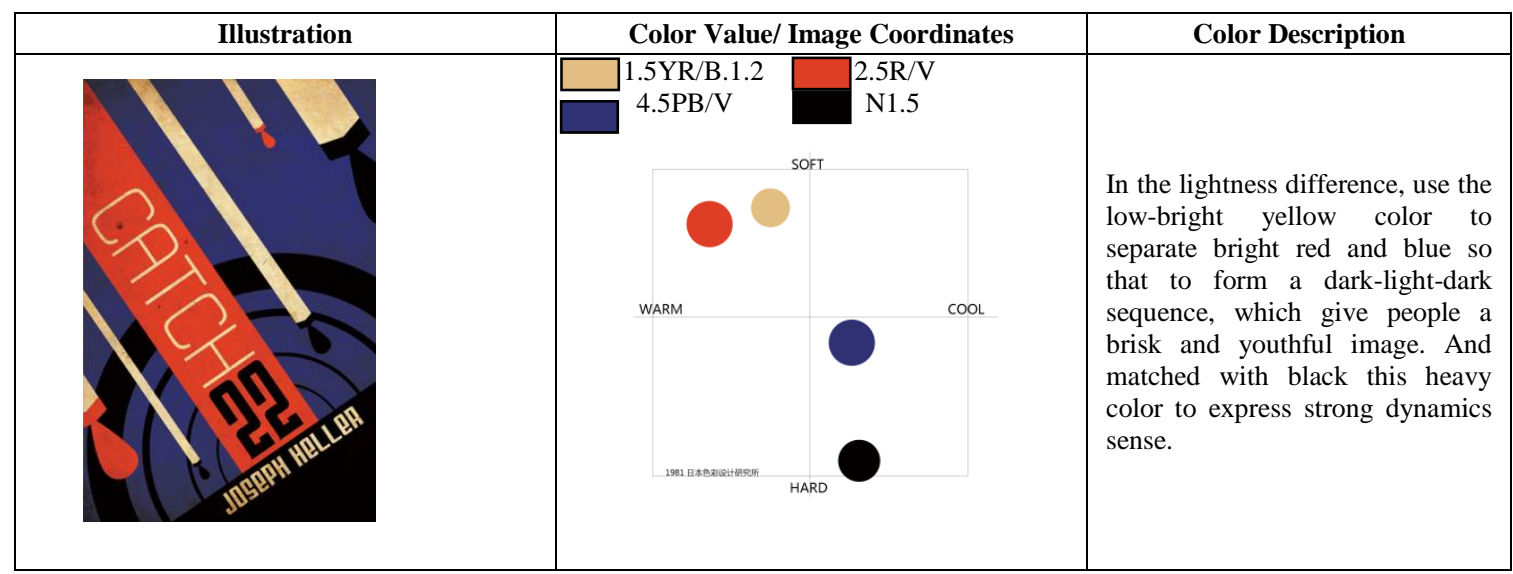

3) Gradient color matching: Gradient color matching method, mainly make sequential and ordered arrangement for the colors in accordance with hue circle, in the picture by embellishing a variety of colors, to create a colorful artistic effect of colorful spots, in the hue changes it gradually transited from soft to hard and from hard to soft. In achromatic lightness, make regular order change from bright to dark and from dark to light, while adding achromatic color to change the hue change, the designer use this way to make production, his purpose is to highlight the overall artistic effect of the screen, present a sense of unity, and create a very strong artistic screen effect.

TABLE IV. COLOR ANALYSIS

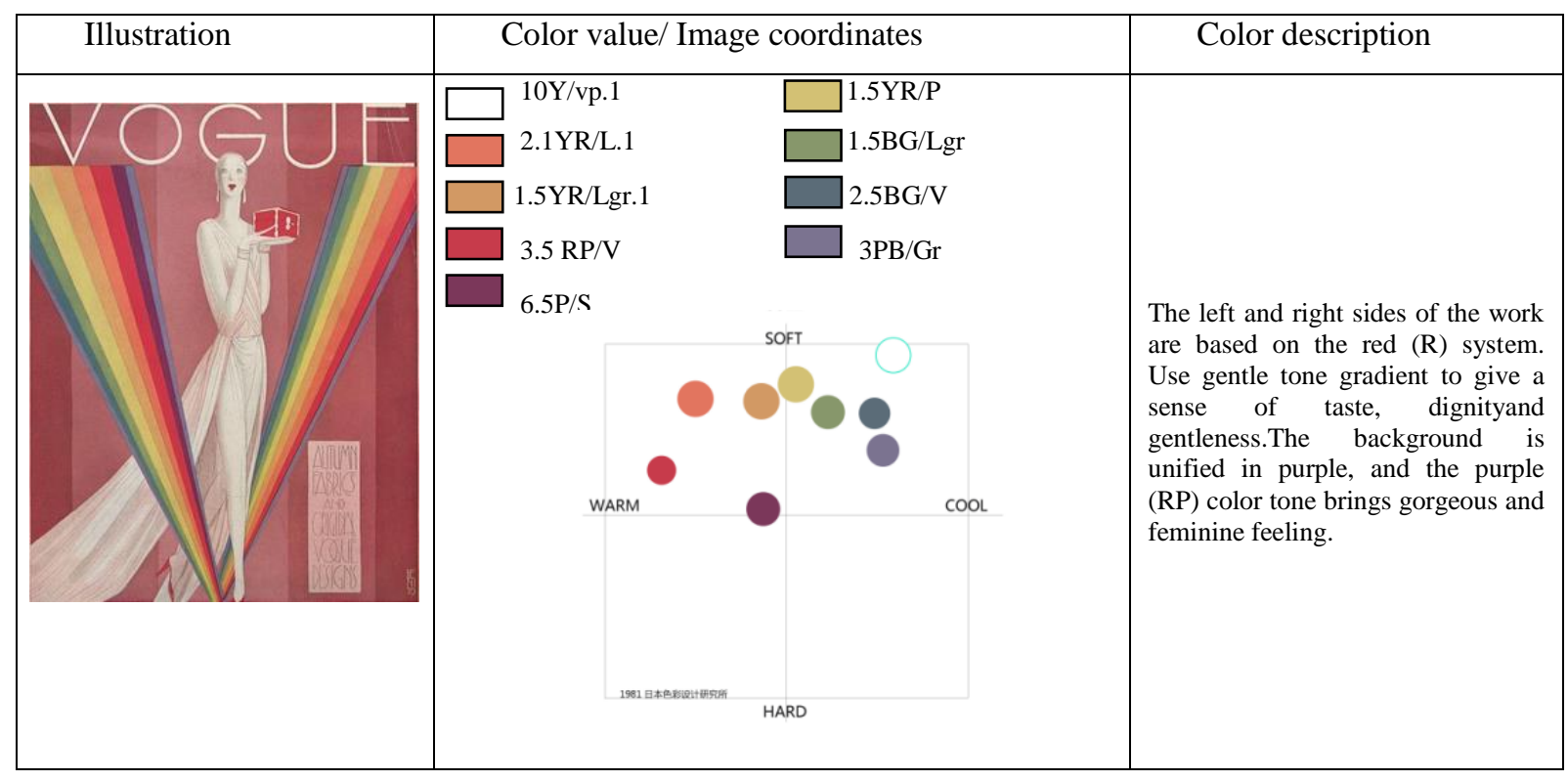

"Table IV" uses this method for color matching. In the whole picture, we can clearly see the collocation of seven different colors, from soft to hard. The tone change from hard to soft, if without these color combinations, the overall picture will be flat and lack of artistic effects. On the contrary, when we apply this seven color to the picture, it will add more artistic effects to the entire picture. The sense of luxury and art in the picture will be stronger and more colorful. This is a typical case of gradient color matching.

\section{B. Color Characteristics of Art-Deco style}

1) Vivid color contrast: The primary feature of Art-Deco style is the vivid color contrast. In Art-Deco design works, we could see more vivid color contrast. The direct use of a large number of contrasting colors adds a strong artistic style to the entire Art-Deco style. This feature is exemplified by the above example that no matter hue matching or color separation matching, designers are very concerned about the contrast of color itself in color selection, emphasizing through 
this strong contrast to highlight the key content of the picture, so that to better highlight the subject of the screen.

In the design process, the Art-Deco style hopes to be able to contrast the themes of the works with this distinctive color contrast method. At the same time, use this way for color matching can also make the screen effect more luxurious and rich, and the luxurious effect of the work itself is transmitted. Early Art-Deco style designers even extracted elements from ancient Egyptian culture, and used the golden and black collocation methods commonly used by ancient Egyptians in practical work design and create many excellent works.

2) Bright color matching: The second feature is bright color matching, that is, use intense contrast method in the color selection to enhance the bright color effect of the picture. Similar to other color matching, the realization of the bright color matching of the Art-Deco style is achieved through the comparison of lightness, purity, and hue. Take purity comparison as an example, in order to create a bright color effect, we must carry out color matching through strong and weak contrasts. On one hand, we use bright colors as the main color of the picture, and on the other hand use low purity color as the auxiliary color of the picture, thus forming a strong contrast effect, and finally achieving bright color matching effect.

3) Feminized obscure: The feminized obscure effect mainly refers to the feminized obscure screen effect created by Art-Deco style that is full of mystery feelings. Such screen effect is mainly through the decoration of various colorful blocks on the warm gray tone background. First the most part of the screen is warm gray, through this way to bring people a calm and soft, light and dignified screen effects, second the addition of some high-purity color patches as embellishments in such a background, thus creating a rich and gorgeous obscure feminine art screen.

TABLE V. COLOR ANALYSIS

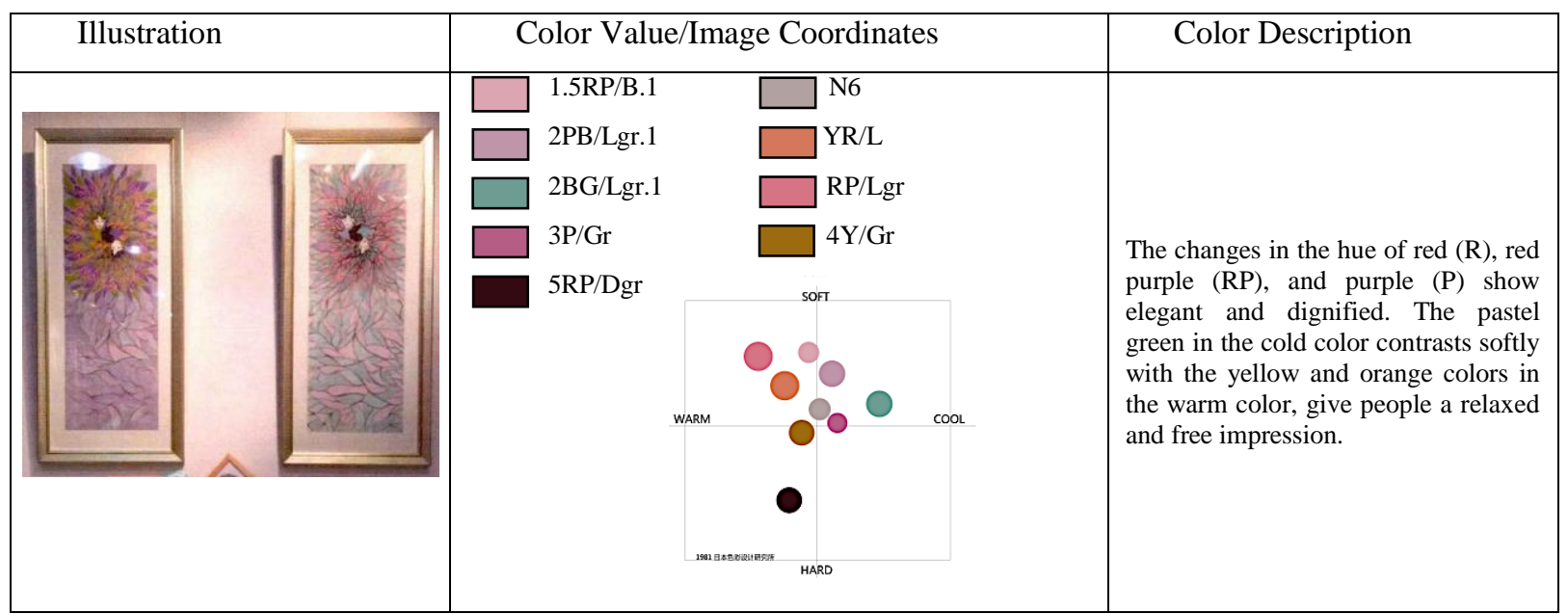

In "Table V", colors such as pink blue, pink green, purple, yellow, and red are used. Although there are many kinds of colors, they are arranged in terms of area and use order. For example, female characters have rich color in facial features, and their eyes are yellow and purple; Reduces brightness or purity to a harmonious red-green contrast effect. The colored area of the eyes is very small so it will not affect the major tone of the pattern. The other large surfaces have uniform colors and even color distribution, blue, green, and pink colors with the same brightness and purity are arranged according to the patterns to form a colored surface with a sense of order. This color combination gives a comfortable visual experience that can bring light and smart home atmosphere.

4) Color flat coating and gradient: The last characteristic of the Art-Deco style color is the flat coating and gradient on the color. First of all, the Art-Deco style is used to draw the picture with a large area of flat coating with the same color, so as to form a very flat screen effect. In terms of color use, except for the garish color, the rest of the colors are filled with a large area of same color, thus giving people a very smooth screen effect.

At the same time, the color of Art-Deco style often uses gradients for color processing and transition different colors in a certain way to create different screen effects. For example, the case in Table 5 is a typical example, in this work, the designer uses emission gradient method to create colorful filling. In shaping the soft image of women, it is an effective color matching technique. The subtle differences in color make it easy for people to understand and become the punchline of whole picture, which added more artistic effects to the entire screen.

\section{The Psychological Influence of Art-Deco Style Color}

1) Luxurious psychological feeling: The first kind of psychological feeling brought by Art-Deco style color is the psychological feeling of luxury. As we all know, the Art-Deco style was born in France, the country of victory in World War I. The country is very wealthy, so the Art-Deco style became one of the most important popular trends at that time. In such 
context, the Art-Deco style pays great attention to the luxury design style. The color selection and color matching of design works focus on the creation of luxurious emotions, use vivid colors or directly use golden color as the main color of the screen, so as to create this psychological feeling.

TABLE VI. COLOR ANALYSIS

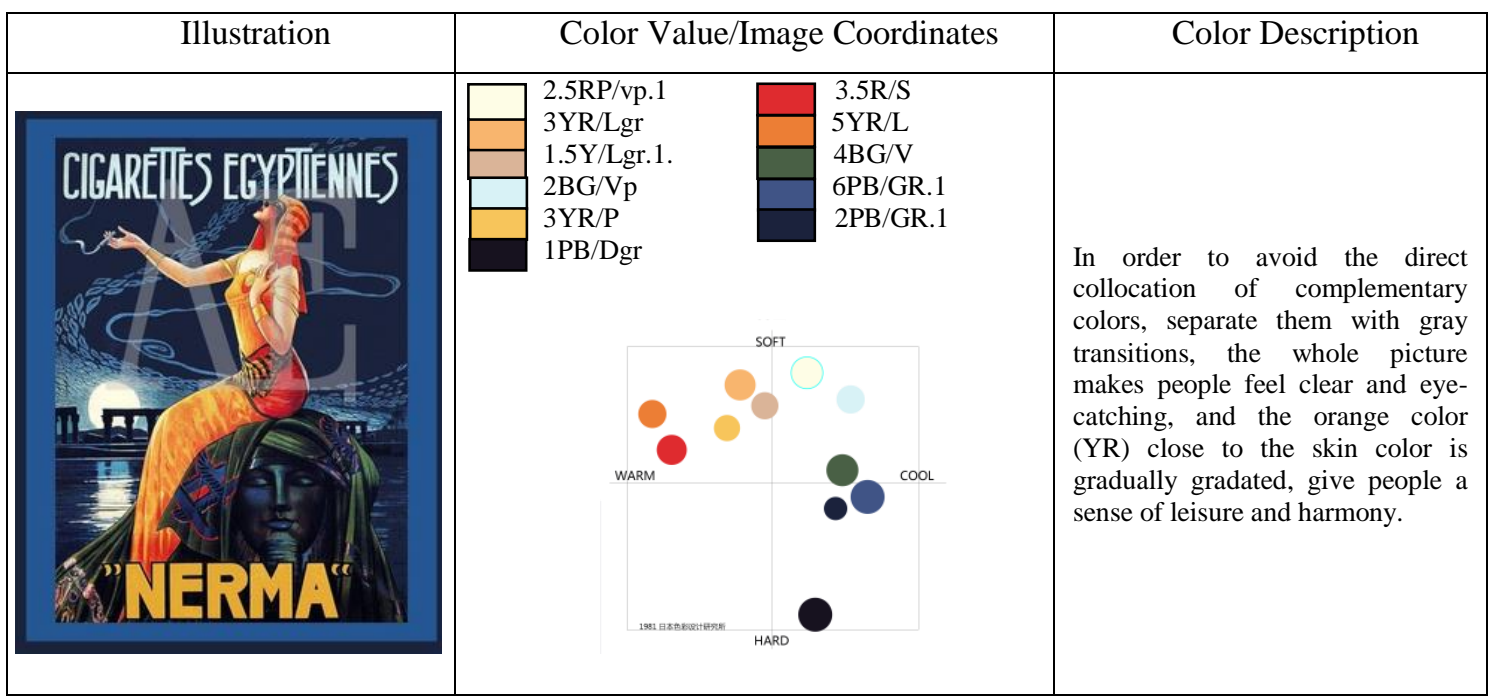

In the picture in "Table VI", in order to create an opulence and grandeur psychological feeling, the designer directly uses the red and yellow colors to shape key figures in the screen, thus creating a very rich feeling. At the same time the background of the screen is more concerned with the color setting in color selection, it uses dark green colors for color matching, further highlights the luxurious emotions of the screen, thus highlighting the luxurious effect of the screen through this color matching method.

2) Warm psychological feeling: The second characteristic of the Art-Deco style color is warm psychological feeling. The formation of this style is also closely related to the social background at that time. In the 1920s and 1930s, Europe was in an economic crisis period. Although the social environment in Paris, France is not too serious, people throughout Europe are in a suffering environment, in order to better alleviate this situation, designers hope to create a warm psychological feeling for people through the screen effect of Art-Deco style, which allow people to hope for life and regain their confidence in life. In order to achieve this goal, designers prefer to use a strong contrast in color matching to create such warm screen effect. For example, the graphic design in "Table VII" uses warm colors as the major tone to create such warm screen effect.

TABLE VII. COLOR ANALYSIS

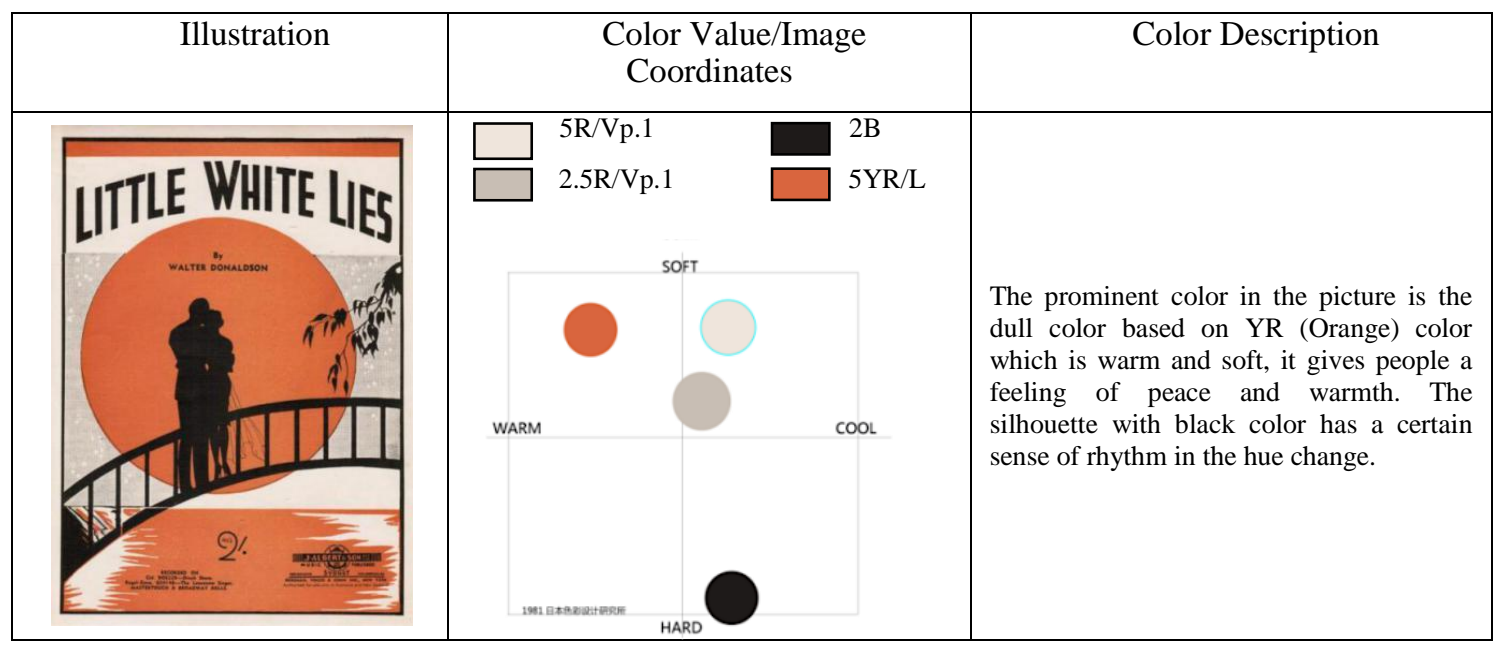

3) Novel psychological feeling: Art-Deco style color can give people novel feelings at the same time. Designers will design some novel screen effects according to their unique color matching. In the process of color matching, in order to 
create this feeling, designers use some popular colors to create the picture. For example, it can be achieved by using the red and yellow this classic matching, and also it can be achieved by using the color red and black, so as to better create this unique style of art. For example, the work in "Table VIII" is such a typical example. In the picture, we can see that the designer uses the red, yellow, black and white four colors to create the picture. The overall picture has a very strong sense of contrast and can bring people a very novel feeling at the same time.

TABLE VIII. COLOR ANALYSIS

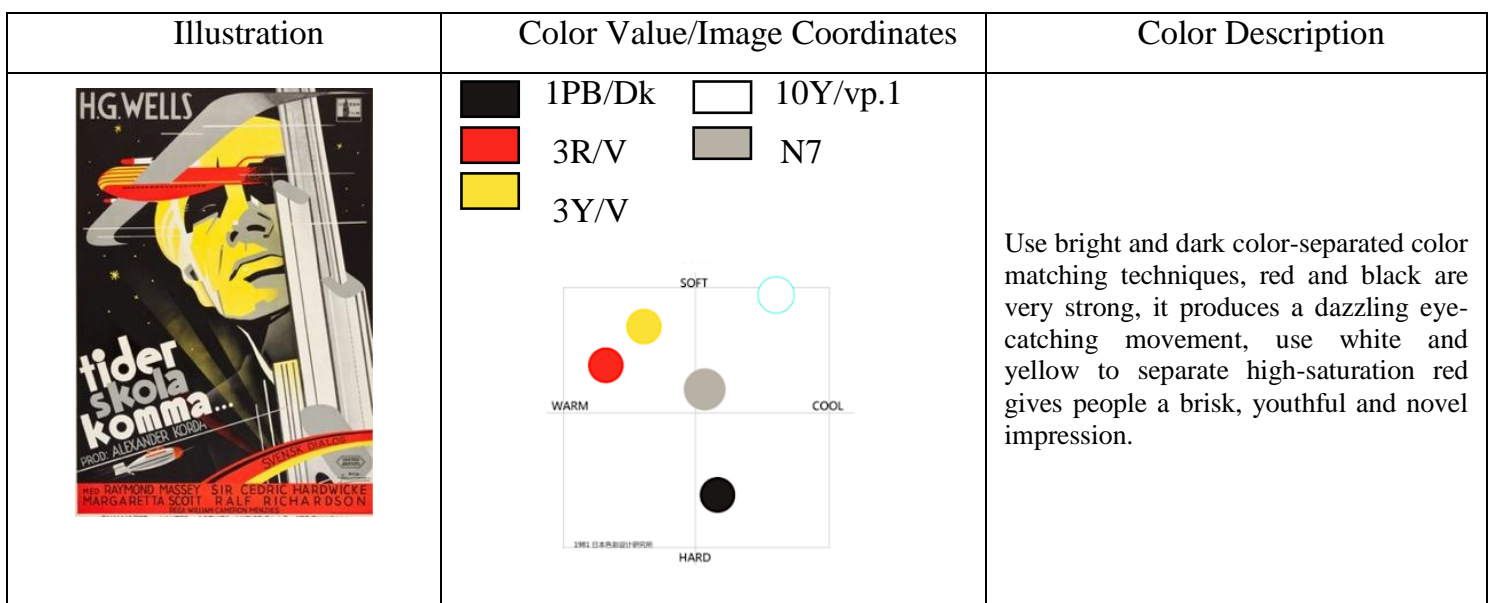

\section{APPLICATION OF THE ART-DECO COLOR APPLICATION PRINCIPLE IN DIFFERENT DESIGN FIELDS}

Although now the Art-Deco style is no longer as popular as it used to be in the design field, it is still deeply loved by people. Designers in many different fields have successively designed through the Art-Deco style to achieve many very outstanding design works. The following is an introduction of the specific applications of Art-Deco style in different design fields.

\section{A. Jewelry Design}

Jewelry design is a very hot design field at present. Jewelry itself pays great attention to its luxury and richness. Jewelry is a symbol and expression of human wealth. Therefore, in the process of designing, the Art-Deco style itself has the kind of luxurious and rich color matching methods used in the design works is the most effective method. Designers can use the kind of Art-Deco style in the color selection of jewelry design, especially use the Art-Deco style hue matching method in the design process of jewelry.

The two pieces of works in "Table IX" are all typical ArtDeco style jewellery designs. The first jewellery design uses transparent red and contrast white color to match, making red more vivid and highlighting the beauty of jewelry. The second picture is a series of jewelry design. This jewelry design uses red, yellow, green, black, and white for the color matching, the entire jewelry work is very enjoyable and shows luxury and prosperity.

TABLE IX. COLOR ANALYSIS

\begin{tabular}{|c|c|l|}
\hline Illustration & \multicolumn{1}{c|}{ Color Description } \\
\hline Color Value/Image Coordinates & $\begin{array}{l}\text { The red in the left picture is bright and } \\
\text { charming, full of enthusiasm, and matched } \\
\text { with white in achromatic color, highlighting } \\
\text { the luxury and richness of jewelry. } \\
\text { In the series of jewelry on the right, use strong } \\
\text { contrasting red and green, white and black } \\
\text { colors. The red purple are accompanied by } \\
\text { golden and black, which makes the red show a } \\
\text { gorgeous appearance in luxury, showing an } \\
\text { exquisite feeling and the overall is decorative. }\end{array}$ \\
\end{tabular}




\section{B. Interior Design}

For interior design, many designers also like to dress up the interior through Art-Deco style, thus creating a novelty and luxurious indoor atmosphere, especially the creation of novel interior atmosphere is pursued by many designers. When designers use Art-Deco style for interior design, the designer pays great attention to the overall matching with the interior environment in terms of color selection, and creates a novel and warm interior environment space through various screen effects.
As in the interior work in "Table X", the starting point of this work is to create a luxurious and warm interior space environment. Therefore, in the design process, the designer chooses black and white, yellow and purple as color matching. First apply the alternate appearance of black and white two colors on the floor, second through some warm yellow wallpaper and decorative paintings to add more warmth and luxury to the interior. The bold matching of dark purple and golden yellow these two complementary colors has a certain sense of contrast. The interior effect created in this way has a strong artistic atmosphere and also gives people a luxurious psychological feeling.

TABLE X. COLOR ANALYSIS

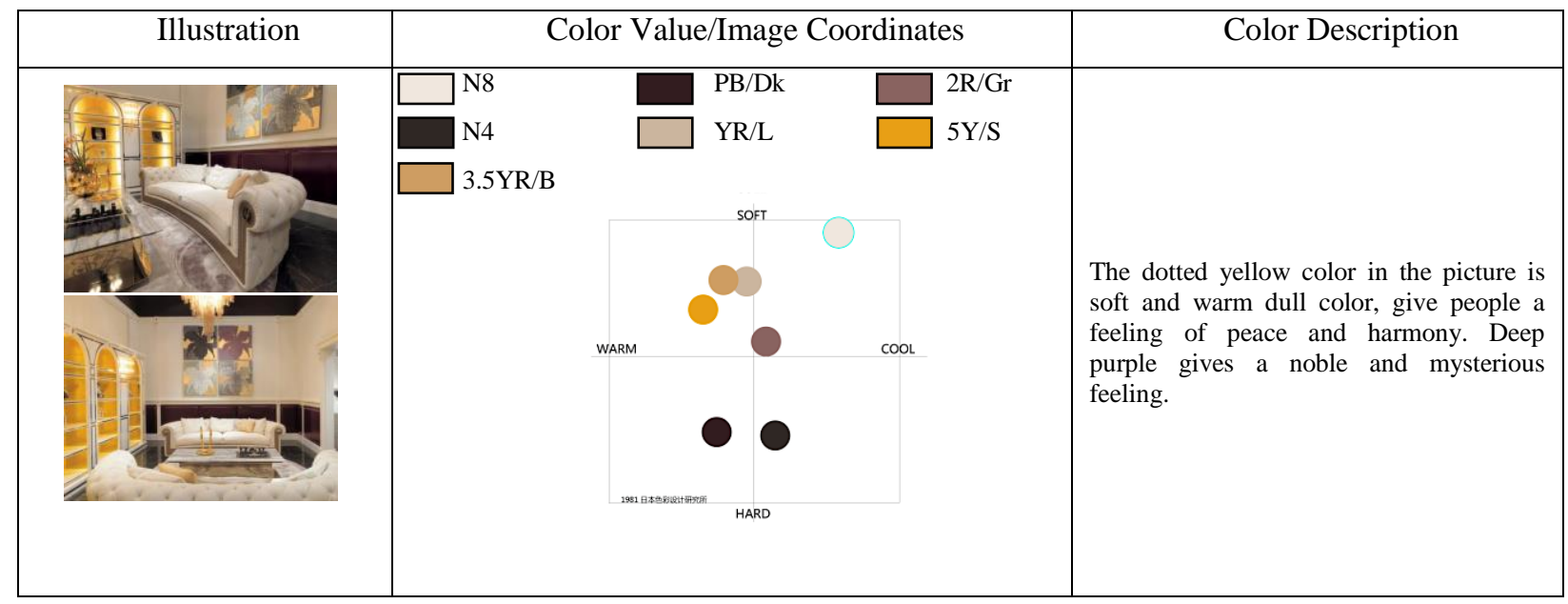

\section{Graphic Design}

There are many application cases about Art-Deco style in graphic design. Many designers have designed through this style. They use different color matching methods to improve the picture form, making the picture effect more interesting and full of novelty.

TABLE XI. COLOR ANALYSIS

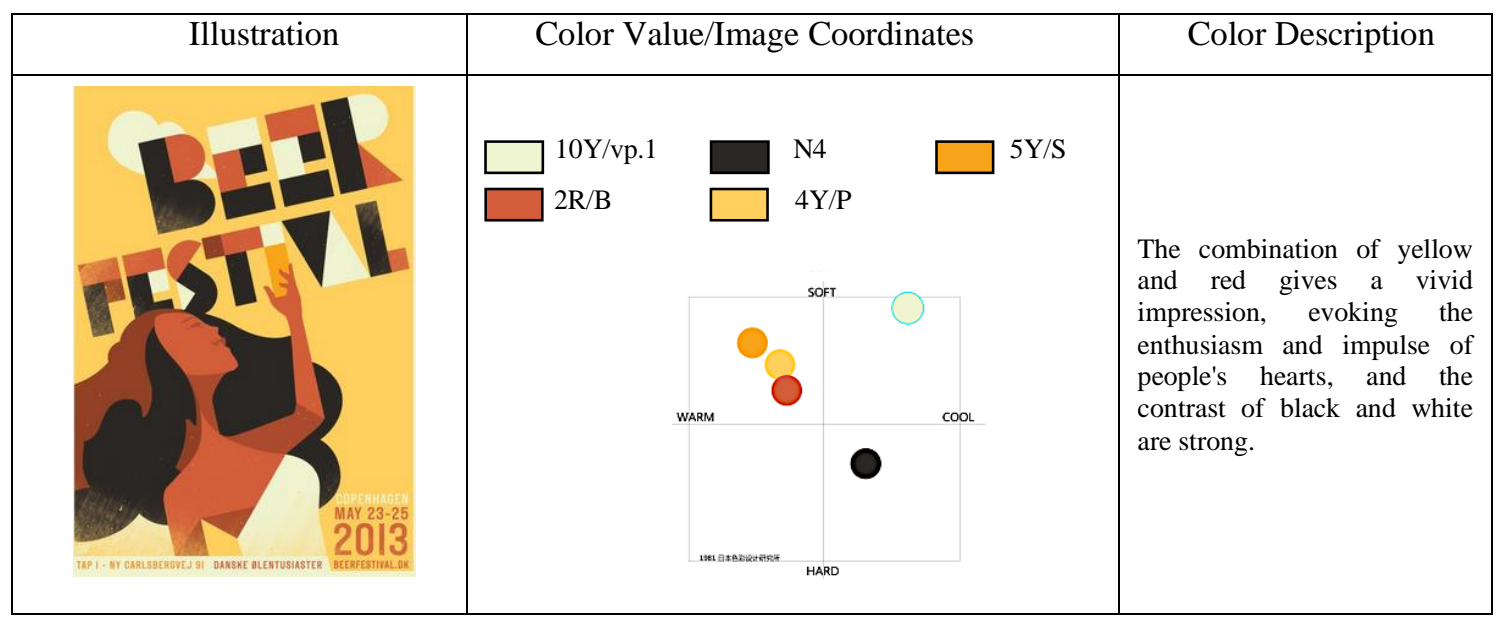

The work in "Table XI" is a typical Art-Deco style art work. In this work, the author uses black, white, yellow, and red four colors for the color matching of the screen effect, the dignified black and dynamic red and yellow add a strong artistic atmosphere for the entire screen, so that the picture has a strong dynamic and artistic effects.

The advertising design work shown in "Table XII" is also a typical Art-Deco style print advertisement work. In this work, 
the designer used red, purple, pink, yellow and white colors for screen processing, among which red $(\mathrm{RP} / \mathrm{V})$ occupies the main color of the picture, so that the entire picture forms a very cheerful art effect.

TABLE XII. COLOR ANALYSIS

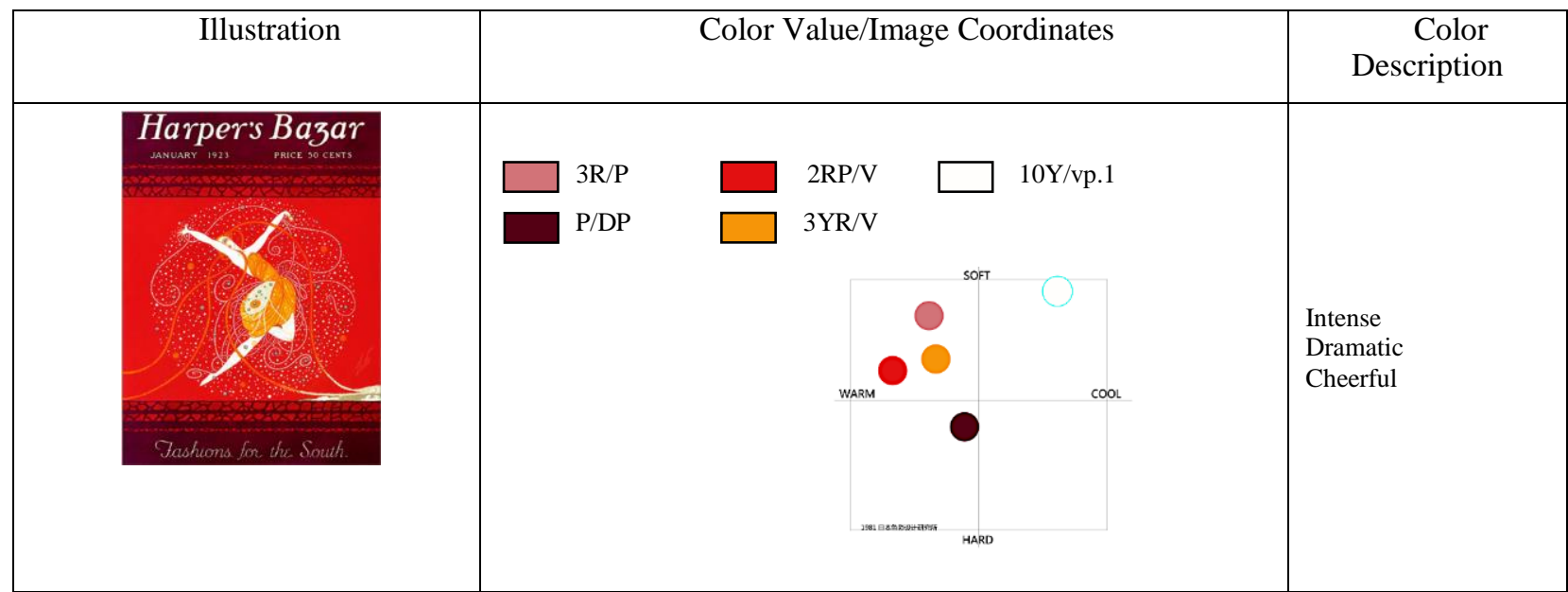

\section{DOLCE \& GABBANA BRAND AND ART-DeCo StYle DESIGN PRACTICES}

\section{A. Brand Features of Dolce \& Gabbana}

Dolce \& Gabbana was able to stand out on the fashion show for the first time at the Milan Fashion Show in 1985. At that time, the brand exhibited three new concept product lines with their own names. The two singers have made a lot of achievements through their continued efforts, and have received unanimous praise from the audience. This brand is the top representative of the new generation of products marked "Made in Italy" and quickly gained worldwide recognition. The first success gave Dolce \& Gabbana great confidence and enabled them to continue to create their own fashion brands with their own unique perspectives on fashion design. Since then, its product range has gradually expanded.

The characteristics of this brand clothing mainly are the followings:

1. The brand's clothing is often used to take the season as a starting point, designing a lot of classic seasonal types of clothing. Such as Italia is my love series, the series of clothing use the Italian landscape and the Sicilian style logo, with lemon as the theme element of the design, costume design series also have some other design styles.

2. "Cool" is also a major characteristics of the Dolce \& Gabbana style. The elements of the street, music, and all contemporary things are inspiration sources of this fashion brand, and the interpretation of unique styles that go beyond the limits set by established rules. Dolce \& Gabbana's fashion is an affirmation of freedom. It is the most authentic expression of an unprecedented contemporary urban style. The design is bold and informal. Dolce \& Gabbana fashion is particularly sought after by trend-makers and all those who are pursuing freedom, cool and rebellious fashion.

\section{B. Concept of Combining Dolce \& Gabbana Brand with Art- Deco}

The color design of the Dolce \& Gabbana flagship store is extremely prominent. The color is closely related to the brand, product style and interior environment. Effective color design allows customers to feel the unique personality and charm of the product brand when they enter the store, which makes consumers' emotional factors sublimate and stimulates their buying desires.

At the same time, the interior design of the store pays attention to both detail and overall planning. Not only it has achieved harmony and coordination, but also has a sense of rhythm and hierarchy, which could attract customers to enter the shop to pick clothes. Therefore, the visual fatigue caused by the customers during shopping can be avoided, thereby preventing the sharp decline in shopping passion.

There are two main ideas for the combination of Dolce \& Gabbana and Art-Deco:

1) Comprehensive use and collocation of contrasting tones: The use of contrasting colors in the color matching of shop windows can give people a large visually impact. The shop window is the first impression the shop, stronger colors can make the shop window area interesting and novelty, which is able to catch people's attention and attract consumers' desire to enter the store. At the same time, contrasting colors can be used to embellish the display area of women's and men's clothing, which could enrich the overall color matching methods and adjust the interior atmosphere of the flagship store.

2) Reasonable use and collocation of neutral colors: When the two colors conflict too much, neutral colors can be used to coordinate. Neutral colors give people a feeling of generosity and calmness, mainly used for the display area of men's wear in stores, and neutral colors should not be applied 
on big area, otherwise people will feel no change, dull, and monotonous. At the same time adding some colored ornaments can enrich the color.

If too many contrasting colors are used to make people uneasy, on the contrary, all use of neutral colors will make people feel too boring and lack of dynamic. So these two methods must be combined to design the color of the store.

\section{Color Analysis and Color Elements Elaboration of Effect Diagram}

The entire space uses the principle of hue matching and color separation. Use red, yellow and blue for color matching and also black and white color, which can add a rich artistic screen effect. At the same time, in order to express the contrastive sense of hue, the separation use of cold colors and warm colors is applied to the entire space.

TABLE XIII. COLOR ANALYSIS

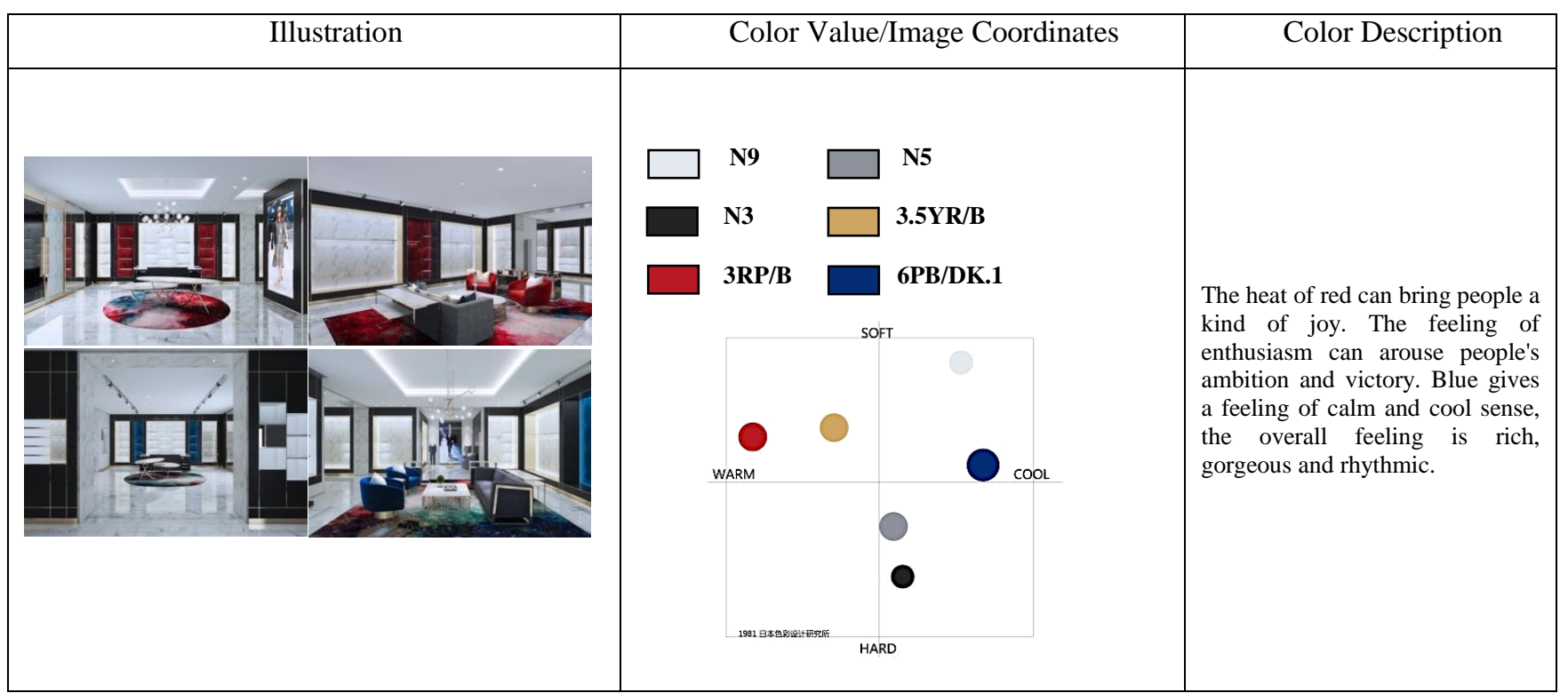

As shown in "Table XIII", inside the entire flagship store, color zones are mainly used to divide the shopping space, hue matching are used to divide the shopping space for men and women. Men and women shopping space is divided by red and blue colors. In order to highlight the high-end luxury of flagship stores, a large number of brass color is used as a decorative element of hard decoration. Black, white and gray are the overall tone, red and blue are coordinated colors, and yellow is the highlight color.

Men's and women's clothing shopping spaces use bright and dark color separation and color matching techniques. In the women's area, red and black are very strong, giving birth to a shining dynamic sense, red can evoke people's emotions such as ambition, determination, joy and victory, use white and golden color to separate the high-saturation red, it brings light, youth and novelty expressions.

The main colors of the men's wear area are blue. The blue color gives people a feeling of generous and steady, reason and calmness. The high-purity color can increase the complementary color effect and maximize the sense of vividness and novelty in the overall space. The overall space, whether visually or psychologically, gives people a strong sense of contrast and attracts consumers' attention.

\section{CONCLUSION}

This article mainly deals with the color matching of ArtDeco style and the application analysis of Art-Deco color in different design fields. It then discusses and explores the color characteristics of Art-Deco style and how to better apply them to the design of Dolce \& Gabbana brand flagship store.

Nowadays people's living standards are gradually improving, people have more rational thinking about their own living and consumption environment, so they have begun to discard the dregs and take the essence in design concepts, and create a comfortable, beautiful, healthy and with distinctive feature shopping environment is people's pursuit. In the future, the development trend in design field will have high demands on the designer themselves, not only they should have good professional skills but also the concept of innovation and higher self-cultivation. In today's people-oriented design, to create a flagship store design that meets people's requirements and conforms to the requirements of the times has an important role and significance for people's material and spiritual life.

\section{REFERENCES}

[1] [Japan] Color Research InstituteofJapan. Color image coordinates. Edited and translated by Li Jun. Beijing: People's Fine Arts Publishing Company, 2006. [日] 日本色彩研究所. 色彩形象坐标. 李军总编 译. 北京: 人民美术出版社, 2006.

[2] [Japan] Color Research InstituteofJapan. Image color matching art. Edited and translated by Li Jun. Beijing: People's Fine Arts Publishing Company, 2006. [日] 日本色彩研究所. 李军总编译. 形象配色艺 术. 北京: 人民美术出版社， 2006 . 
[3] [Japan] Color Research InstituteofJapan. Color psychology analysis.Edited and translated by Li Jun. Beijing: People's Fine Arts Publishing Company, 2006. [日] 日本色彩研究所. 李军总编译. 色 彩心理探析. 北京: 人民美术出版社， 2006.

[4] [Switzerland] Johannes Eton. Color Art. Translated by Du Dingyu. Shanghai: Shanghai People's Fine Arts Publishing Company, 1985. [瑞 士] 约翰内斯・伊顿.色彩艺术.杜定宇译.上海: 上海人民美术出版 社, 1985.

[5] [USA] Thompson. Edited and translated by Sun Deng. Visual psychology. Beijing: China Architecture \& Building Press. 1989. [美] 汤普森著.孙等编译.视觉心理学.北京:中国建筑工业出版社. 1989.

[6] Zhang Peifeng. Discussion of Fuzhou city color problem. Master Thesis. Fujian: Fujian Normal University. 2006. 张培枫。福州市城市色彩问 题探讨. 硕士学位论文. 福建: 福建师范大学. 2006.

[7] Kandinsky. The Spirit of Art. Yunnan: Yunnan People's Publishing Company, 1999. 康定斯基. 论艺术的精神.云南: 云南人民出版社, 1999.

[8] Zhuang Ziping. ClassicPattern color matching. Beijing: Beijing Arts and Crafts Publishing Company2005. 庄子平.图案配色经典.北京: 北京工艺美术出版 2005 .

[9] Huang Guosong. Color Design. Beijing: China Textile Press. 2003 黄 国松.色彩设计学.北京: 中国纺织出版社.2003

[10] Li Li. Color Design and Expression in Environmental Art. Guangxi: Light Industry Textiles and Design, 2007.9. 李莉. 论环境艺术中的色 彩设计与表现.广西:轻工业纺织与设计, 2007.9.

[11] Zhang Zhengyang. Importance of color in decorative arts. 2014. No. 14: 249. 张正阳.色彩在装饰艺术中的重要性.2014.第 14 期: 249 .

[12] Li Xinghua. Zhou Hui. Several problems that should be noticed in color matching. Journal of Nanchang Junior College. 2009. No. 4: 54-55 李 杏花.周晖.浅谈色彩搭配应注意的几个问题.南昌高专学报.2009.第 4 期: 54-55

[13] Zhang Sicong. Store Color design inthe clothing brand VMD strategy. The first Asian Color Forum Papers. 2004. 张思聪.服装品牌 VMD 战 略中的卖场色彩设计.首届亚洲色彩论坛论文 集.2004.

[14] Wang Zhixiang. The color planning and design of clothing store display. Tianjin Textile Science and Technology, 2009. 187: 47-50. 王芝湘.论 服装卖场陈列的色彩规划设计.天津纺织科技.2009.第 187 期: 47-50.

[15] Yang Chuan. Costume display design. Beijing: Chemical Industry Press. 2008-9. 阳川.服饰陈列设计.北京：化学工业出版社.2008-9.

[16] Chen Hang. Art Deco Movement and Its Style. Shanxi Architecture, Vol. 36 No. 14: 47-48. 陈航. 装饰艺术运动及其风格. 山西建筑, 2010.第 36 卷第 14 期: $47-48$.

[17] Peng Wenli. Research on the relationship between furniture materials and design. Hunan. Central South University of Forestry Technology. Master Thesis 2005. 彭文利. 家具材料与设计的关联性的研究.湖南. 中南林业科技大学硕士学位论文.2005 